\title{
SUSTAINABILITY OF THE TEXTILE WASTE STREAM IN MACEDONIA
}

Sonja Jordeva ${ }^{1 \star}$, Elena Tomovska² ${ }^{2}$ Kiro Mojsov ${ }^{1}$ Saška Golomeova-Longurova ${ }^{1}$ Stefan Maksimov ${ }^{1}$

${ }^{1}$ Faculty of Technology, University "Goce Delchev", Shtip, Macedonia

2Faculty of Technology and Metallurgy, University "Ss Cyril and Methodius", Skopje, Macedonia

In Macedonia, as a country with a developed apparel industry, a significant amount of pre-consumer textile waste is generated, more precisely apparel cutting waste. The aim of this paper is to make an accurate estimate of its quantity, as well as the characterization based on the raw material composition as a prerequisite for its further handling. Before any recycling initiative for textile waste, an analysis should be made of whether its quantity and quality can ensure the continuity of the recycling process. The analysis shows that the amount of apparel cutting waste is a fairly constant value (in the period from 2009 to 2014 an average of 3,377 tons of apparel cutting waste was generated annually). The waste from cotton and cotton blends is most common. Despite the constant annual amount of apparel cutting waste and numerous reasons for its recycling, almost all this waste ends in landfills.
(PROFESSIONAL PAPER)

UDC 677:628.4.042:502.174.1 (497.7)

Keywords: textile industry, apparel cutting waste, recycling

\section{Introduction}

Textile is one of the main products without which the mankind cannot be imagined. Manufacturing processes in the textile industry are diverse and complex, with everyday challenges and continuous tracking of the taste of millions of consumers, individual styles and financial opportunities. Textile and clothing industries include a range of activities, from the production of fibres and their transformation into yarns, fabrics, knitwear or nonwovens, subsequently used not only in the clothing industry, but also in the construction industry, the automobile industry, medicine, sports etc. The generation of textile waste is influenced by the production of textile products. The higher the production of textile products, the greater the quantities of textile waste. The increases in the production and consumption of textiles and clothing are the result of the increase in living standards and the increasing number of people, that is, they are the functions of consumers' demands under the influence of the state of economy [1].

The world production of textile fibres has recorded a steady increase in the past few decades. In 2004 it was more than 64 million tonnes. The global textile consumption is estimated at more than 30 million tonnes per year [2]. These facts show how much textiles are present in the environment.

The high consumption of textiles is mostly affected by changes in fashion trends. The driving force in fashion is a change, that is, the need for frequent replacement of still functional textile products with new, more modern ones. Textile companies have seasonal collections in order to attract customers and make profits. It is a two-edged sword because it stimulates the production, but the problem of waste occurs, that is, the problem of excessive consumption of textiles. [3].

In the textile and clothing production, solid waste is generated at any point of the supply chain in the form of fibres, yarns or fabric cuttings. Apart from textiles, nontextile waste with the dominant presence of paper and cardboard, glass, plastics and metal parts is also being created. $[4,5]$.

Textile waste is composed of natural and synthetic polymer materials such as cotton, polyester, nylon, polypropylene and others. The primary source of raw material for the production of synthetic polymeric materials is oil. In addition, the production of renewable sources of natural polymers like cotton requires energy and chemicals, based on non-renewable resources. Although global oil reserves can last for at least a few hundred years according to the rate of the current consumption, oil and other natural resources, in practical terms, are non-renewable [6].

The textile waste management has ecological and economic components. All phases of textile waste reusing or recycling enable the preservation of an important resource. Theoretically, textiles are almost $100 \%$ recyclable, therefore nothing in the textile industry should go to waste. Textile waste is classified into three groups, as follows:

1. Textile waste generated before use (pre-consumer) - it represents the waste of the production which occurs in the processing of fibres while forming yarns, fabrics, knitted and non-wovens, textile products, including residues when cutting the materials (cuts, exfoliants or secondclass textiles);

\footnotetext{
*Author address: Sonja Jordeva, University “Goce Delchev”, Faculty of Technology, Shtip, Miro Baraga bb., Probishtip, R Makedonija

E-mail: sonja.jordeva@ugd.edu.mk

The manuscript received: March, 23, 2018.

Paper accepted: May, 05, 2018.
} 
2. Textile waste generated after use (post-consumer) - it represents all types of clothing or textiles for households which has no longer usability value for consumers is thrown away, regardless of whether it is poured, damaged, superficially or simply out of fashion trends;

3. Industrial textile waste - the waste generated from textile manufacture for commercial or industrial purposes, including textile waste from the manufacturing of carpets and curtains and hospital waste [7].

In order to recycle the textile waste to fibres and return it to the spinning process, it must first be sorted by the raw material composition and by colour. This is especially important for textile companies that have a manufacturing process from fibres to a ready-made product. If the textile material is not sorted, it can be recycled as pellets and used in the construction as insulating material, in the automotive industry as a composite material or as filler material in the furniture industry. It is necessary to have the coordination between the companies that produce textile waste and the companies for collecting, transporting and processing the waste. For the apparel companies, the most economical are the services of companies the main activity of which is the processing of waste [6].

The generation of textile waste cannot be avoided, so the main issue is how to deal with it. The most popular global management principle with the textile waste was set by Fletcher known as three "R": reduction, reuse, recycling. El Haggar considered that the principle is based on 7 "R": (reduce, reuse, recycling, regulations, recovery, rethinking and renovation). [5]. Unfortunately, the linear model of resource utilization dominates in the world - produce, use once and throw away, the model set at the beginning of industrialization. Linear use models differ from cyclical and sustainable flows in nature, where waste is used as a resource again in subsequent processes. [8].

In order to achieve the compatibility between the textile and textile industry and the concept of sustainable development, the principles of sustainability must be incorporated in all segments of the production starting from the design (eco-design), using sustainable raw materials and sustainable production methods, through the final disposal at the end of the life cycle of the product.

In all countries with a developed textile production, a large amount of pre-consumer textile waste is generated. Macedonia is among the countries with a developed textile industry, more precisely apparel industry, as a result of which large quantities of apparel cutting waste are generated.

When considering waste recycling, it is clear that its quantity and quality are the most important factors, but it must be borne in mind that only sorted waste can be recycled. Therefore, the goal of this paper is to make a longitudinal analysis of the quantity and quality of the waste generated, in order to determine if the waste is sustainable.

Analysis of the quantity and quality of textile waste in the period from 2009 to 2014

Textile and clothing manufacturing have a long tradi- tion in Macedonia. Until 1995, the basic textile industry was developed, and today Macedonia belongs to the countries with a developed apparel industry $(95 \%$ of the textile production belongs to the apparel industry). Around 395 registered companies in Macedonia work with apparel manufacturing, producing more than 10 million pieces annually. Even though they are spread across the whole country, the largest number of companies - 119 (or 30\%) are located in the East region. This industrial activity employs 31,742 employees or $6.1 \%$ of Macedonia's working population. Compared to 2012, a $4.8 \%$ decrease is noted. In $93 \%$ of production facilities the apparel production is organized according to the CMT (Cut, Make \& Trim) system to supply foreign markets, mostly European countries. In the total export, the textile industry participates with $26 \%$ $[9,10]$. As a result of this situation, a large amount of preconsumer textile waste is generated.

For the estimation of the quantity of generated textile waste, as well as for its characterization according to the raw material composition, the data from the State Statistical Office [10] were used as follows: Statistical Yearbook for the period 2009-2014, and the publications Foreign trade exchange in the same period. Based on the data from these documents, a tabular presentation of the export of textile products according to the raw material composition in the mentioned period was prepared. The obtained results are given in Table 1.

Table 1. Export of apparel from R.Macedonia (2009 to 2014) by the raw material composition

\begin{tabular}{|c|c|c|c|c|c|c|c|}
\hline \multirow{3}{*}{ No. } & \multirow{3}{*}{ Name } & \multicolumn{6}{|c|}{ Quantity (tonnes) } \\
\hline & & \multicolumn{6}{|l|}{ Year } \\
\hline & & 2009 & 2010 & 2011 & 2012 & 2013 & 2014 \\
\hline 1 & Men's cotton shirts & 2348 & 2395 & 2591 & 2349 & 2243 & 2292 \\
\hline 2 & Women's cotton shirts and blouses & 1894 & 1658 & 1381 & 847 & 791 & 680 \\
\hline 3 & $\begin{array}{l}\text { Women's shirts and blouses made of artificial and } \\
\text { synthetic fibres }\end{array}$ & 1758 & 1361 & 962 & 924 & 904 & 916 \\
\hline 4 & Women's pants made of synthetic fibres & 1287 & 1468 & 1334 & & 1146 & 178 \\
\hline 5 & Men's jackets and suits made of synthetic fibres & 550 & 621 & 688 & & 551 & 630 \\
\hline 6 & Men's synthetic pants & 761 & 764 & 970 & 803 & 864 & 1002 \\
\hline 7 & Cotton men's trousers and shorts & 1093 & 1075 & 1340 & 1113 & 1041 & 1283 \\
\hline 8 & Cotton women's trousers and shorts & 722 & 736 & 857 & 939 & 1281 & 1147 \\
\hline 9 & $\begin{array}{l}\text { Women's jackets and suits made of synthetic } \\
\text { fibres }\end{array}$ & 431 & 400 & 351 & & & \\
\hline 10 & $\begin{array}{l}\text { Cotton sweatshirts and short-sleeve T-shirts, } \\
\text { knitted or crocheted }\end{array}$ & 819 & 995 & 976 & 955 & 957 & 1027 \\
\hline 11 & $\begin{array}{l}\text { Underpants and T-shirts with short sleeves, knitted } \\
\text { or crocheted from other materials }\end{array}$ & 576 & 523 & 738 & 621 & 675 & 765 \\
\hline 12 & $\begin{array}{l}\text { Women's shirts and blouses, knitted or crocheted } \\
\text { from artificial or synthetic fibres }\end{array}$ & 723 & 527 & 628 & 698 & 849 & 911 \\
\hline 13 & Linen, knitted or crocheted, cotton & & 1041 & 1007 & 892 & 988 & 954 \\
\hline 14 & Linen made of other textile materials & 464 & & 375 & 397 & & 389 \\
\hline 15 & Skirts and skirts - pants made of synthetic fibres & 470 & 396 & & & & \\
\hline 16 & Dresses made of synthetic fibres & 219 & 241 & & & & \\
\hline 17 & $\begin{array}{l}\text { Other men's clothing made of artificial or synthetic } \\
\text { fibres }\end{array}$ & & 379 & & & & \\
\hline 18 & $\begin{array}{l}\text { Cotton shirts and shirts-blouses, knitted or } \\
\text { crocheted }\end{array}$ & 937 & 603 & 643 & 1029 & 1032 & 982 \\
\hline 19 & Other men's clothing made of cotton & 334 & 435 & & & & \\
\hline 20 & $\begin{array}{l}\text { Women's coats, wool and pellet wool and fine } \\
\text { animal hair }\end{array}$ & 134 & 198 & 260 & 201 & 202 & 173 \\
\hline
\end{tabular}


Table 1 (continued)

\begin{tabular}{|c|c|c|c|c|c|c|c|}
\hline 21 & $\begin{array}{l}\text { Jackets and suits for women or girls made of } \\
\text { cotton }\end{array}$ & 150 & 159 & 237 & 311 & 490 & 384 \\
\hline 22 & $\begin{array}{l}\text { Jackets and suits for women or girls made of wool } \\
\text { or fine animal hair }\end{array}$ & 163 & 159 & 138 & & & \\
\hline 23 & Other women's clothing made of cotton & 97 & & & & & \\
\hline 24 & $\begin{array}{l}\text { Other women's clothing made of artificial and } \\
\text { synthetic fibres }\end{array}$ & 324 & 363 & & & & 422 \\
\hline 25 & Men's jackets and suits made of cotton & 240 & 231 & 371 & 927 & 247 & 355 \\
\hline 26 & $\begin{array}{l}\text { Women's pants and shorts made of other textile } \\
\text { materials }\end{array}$ & 176 & 202 & 252 & 180 & 277 & 263 \\
\hline 27 & Cotton dresses & 92 & 113 & 96 & 101 & 90 & 78 \\
\hline 28 & Dresses made of other textile materials & 48 & & & & & \\
\hline 29 & Skirts and skirts -pants made of cotton & 151 & 132 & 135 & 119 & 131 & 131 \\
\hline 30 & $\begin{array}{l}\text { Jackets and suits for women or girls made of other } \\
\text { textile materials }\end{array}$ & 68 & 93 & 106 & 97 & & \\
\hline 31 & $\begin{array}{l}\text { Men's panties (long or short) made of cotton, } \\
\text { knitted or crocheted }\end{array}$ & 262 & 279 & 269 & 221 & 278 & 317 \\
\hline 32 & Men's shirts made of artificial and synthetic fibres & 86 & 107 & 126 & 109 & 75 & 108 \\
\hline 33 & $\begin{array}{l}\text { Women's pants and shorts made of wool and fine } \\
\text { animal hair }\end{array}$ & 82 & 101 & 103 & 52 & 51 & 54 \\
\hline 34 & Skirts and skirts-wool pants and fine animal hair & 79 & 101 & 74 & & & \\
\hline 35 & Cotton terry & 333 & 377 & 288 & 309 & 375 & 414 \\
\hline 36 & Other men's clothing & 37 & 31 & 26 & 16 & & \\
\hline 37 & $\begin{array}{l}\text { Another men's clothing made of artificial and } \\
\text { synthetic fibres }\end{array}$ & 213 & & 338 & 408 & & \\
\hline 38 & $\begin{array}{l}\text { Women's shirts and shirts blouses, knitted or } \\
\text { crocheted of other textile materials }\end{array}$ & 88 & 124 & 63 & & 17 & \\
\hline 39 & $\begin{array}{l}\text { Skirts and skirts-trousers made of other textile } \\
\text { materials }\end{array}$ & 96 & 62 & 69 & 93 & 77 & 55 \\
\hline 40 & $\begin{array}{l}\text { Sweaters with or without fastening, semi-seams, } \\
\text { vests, knitted or crocheted of cotton }\end{array}$ & 196 & 144 & & & & \\
\hline 41 & $\begin{array}{l}\text { Sweaters with or without fastening, pullovers, } \\
\text { vests made of artificial or synthetic fibres }\end{array}$ & 209 & & 126 & 105 & 142 & 109 \\
\hline 42 & $\begin{array}{l}\text { Dresses made of synthetic fibres, knitted or } \\
\text { crocheted }\end{array}$ & & 139 & & 111 & & 131 \\
\hline 44 & $\begin{array}{l}\text { Men's pants and shorts made of wool and fine } \\
\text { animal materials }\end{array}$ & & 71 & 97 & 99 & 86 & 103 \\
\hline 45 & Male sets made of synthetic fibres & 25 & 36 & 28 & & 23 & \\
\hline 46 & $\begin{array}{l}\text { Men's coats, mantles, pelerins and windbreaks } \\
\text { made of artificial or synthetic fibres }\end{array}$ & 46 & 26 & 106 & 59 & 56 & 74 \\
\hline 47 & $\begin{array}{l}\text { Women's shirts and shirts-blouses made of other } \\
\text { textile materials }\end{array}$ & & 49 & 55 & 52 & & \\
\hline 48 & Coats made of artificial or synthetic fibres & & 41 & & & & \\
\hline 49 & $\begin{array}{l}\text { Men's coats, and pellet made of wool and fine } \\
\text { animal hair }\end{array}$ & 73 & 68 & 110 & & & \\
\hline 50 & Female coats made of artificial and synthetic fibres & 54 & & 46 & & 54 & 66 \\
\hline 51 & Pajamas made of cotton, knitted or crocheted & & 154 & & & & \\
\hline 52 & Dresses made of artificial and synthetic fibres & & 55 & 246 & 255 & 243 & 361 \\
\hline 53 & $\begin{array}{l}\text { Dresses made of artificial and synthetic fibres, } \\
\text { knitted or crocheted }\end{array}$ & & & 237 & 134 & 264 & 129 \\
\hline 54 & $\begin{array}{l}\text { Women's jackets and suits made of other textile } \\
\text { materials }\end{array}$ & & & & 79 & 184 & 235 \\
\hline 55 & Other men's clothing made of cotton & & & 574 & 547 & 343 & 323 \\
\hline 56 & Skirts and skirts pants made of synthetic fibres & & & 326 & 271 & 270 & 297 \\
\hline 57 & $\begin{array}{l}\text { Skirts and skirts trousers made of synthetic fibres, } \\
\text { knitted or crocheted }\end{array}$ & & & 98 & & & 97 \\
\hline 58 & $\begin{array}{l}\text { Other women's clothing made of artificial or } \\
\text { synthetic fibres }\end{array}$ & & & 296 & 234 & 343 & \\
\hline
\end{tabular}

Table 1 (continued)

\begin{tabular}{|c|c|c|c|c|c|}
\hline 59 & $\begin{array}{l}\text { Dresses made of other textile } \\
\text { materials }\end{array}$ & 30 & & & \\
\hline 60 & $\begin{array}{l}\text { Other women's clothing made of } \\
\text { cotton }\end{array}$ & 74 & & & \\
\hline 61 & $\begin{array}{l}\text { Women's pants and shorts made of } \\
\text { synthetic fibres }\end{array}$ & & 1111 & & 1024 \\
\hline 62 & $\begin{array}{l}\text { Women's jackets and suits made of } \\
\text { synthetic fibres }\end{array}$ & & 360 & 405 & 470 \\
\hline 63 & $\begin{array}{l}\text { Women's jackets and suits made of } \\
\text { wool and fine animal hair }\end{array}$ & & 108 & 88 & 95 \\
\hline 64 & $\begin{array}{l}\text { Cotton female slip panties, knitted } \\
\text { or crocheted }\end{array}$ & & 122 & & 140 \\
\hline 65 & $\begin{array}{l}\text { Women's pants and shorts made of } \\
\text { other fibres, knitted or crocheted }\end{array}$ & & & & 94 \\
\hline 67 & $\begin{array}{l}\text { Male windproof jacket made of } \\
\text { cotton }\end{array}$ & & & & 52 \\
\hline 68 & $\begin{array}{l}\text { Men's jackets and suits made of } \\
\text { wool and fine animal hair }\end{array}$ & & & & 42 \\
\hline
\end{tabular}
Total

\begin{tabular}{llllll}
18939 & 19262 & 20265 & 18384 & 18167 & 19794 \\
\hline
\end{tabular}

The total export of the textile industry in the period from 2009 to 2014 is 114811 tonnes, out of which the largest export was recorded in 2011 with 20265 tonnes, while the smallest export occurred in 2013 with 18167 tonnes.

If we take into account that the amount of waste in cutting has an average value of $15 \%$, the generated waste from cutting (according to Table 1) is 20260 tonnes for the period 2009-2014. The annual analysis shows that in 2009 the amount of waste was $3342.17 \mathrm{t}$., $3399.17 \mathrm{t}$ in 2010, 3576.16 $t$ in 2011, $3244.24 t$ in 2012, $3205.94 t$ in 2013, and $3493.05 \mathrm{t}$ in 2014 (Figure 1).

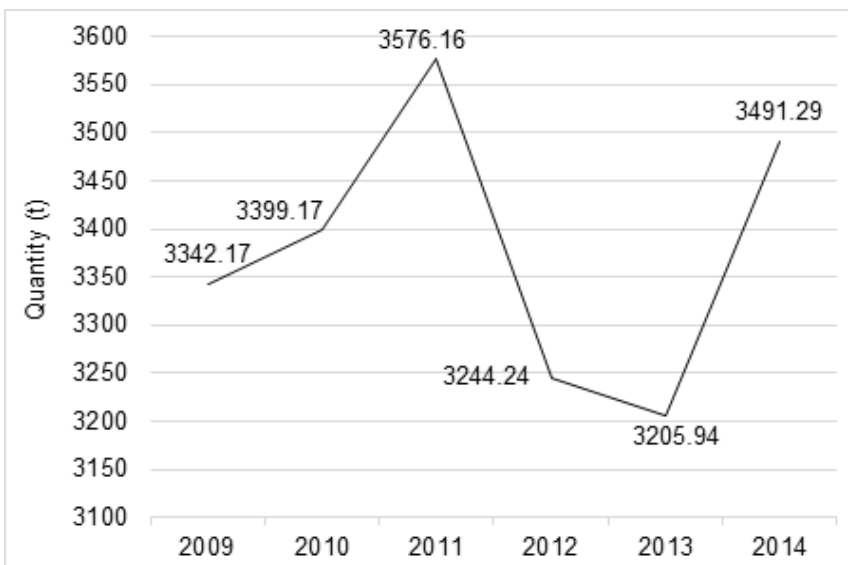

Figure 1. Quantity of textile waste in the period from 2009 to 2014

In order to compare the results of the first and second three years of the investigated period, they are shown separately in Figure 2 and Figure 3.

In the period from 2009 to 2011, the total generated cutting waste was 10317.5 tonnes, out of which 5476.58 tonnes or $53.08 \%$ was cotton waste, 3703.4 tonnes or $35,89 \%$ synthetic or man-made fibres, 354.88 tonnes or $3,44 \%$ of wool or fine animal hair and 782.64 tonnes or $7.58 \%$ of waste with other raw materials (Figure 2 ).

In the period from 2012 to 2014 , the total generated cutting waste was 9943.23 tonnes, out of which 5581.23 tonnes or $56,13 \%$ was cotton waste, 3299.3 tonnes or $33.18 \%$ synthetic or artificial fibres, 238.94 tonnes or 
$2.4 \%$ of wool or fine animal hair and 823.76 tonnes or $8.28 \%$ of waste with other raw materials (Figure 3 ).

In the period from 2012 to 2014, the generated cotton waste increased by $3.05 \%$ compared to the period from 2009 to 2011, while synthetic or man-made fibres appear to have a smaller volume of $2.71 \%$ compared to the same period. The waste of fine wool or fine animal hair appears to be smaller by about $1 \%$, while the waste with other raw material composition is growing by about $0.7 \%$ compared to the period $2009-2011$.

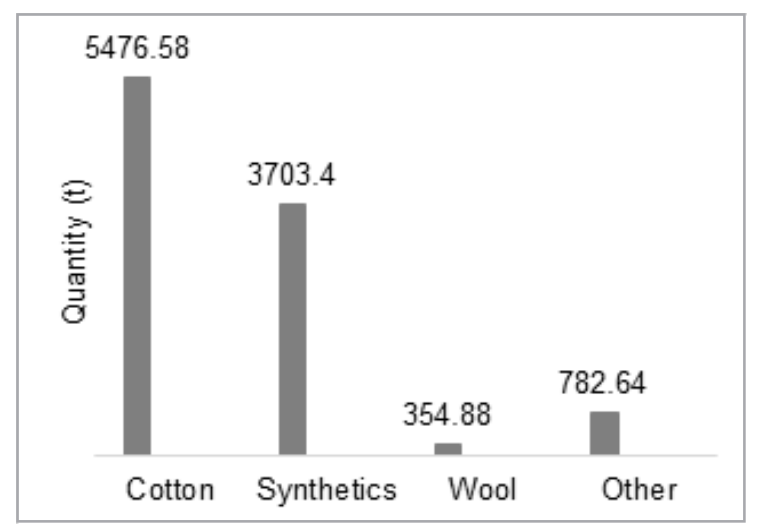

Figure 2. Average quantity of apparel cutting waste by raw material composition (2009-2011)

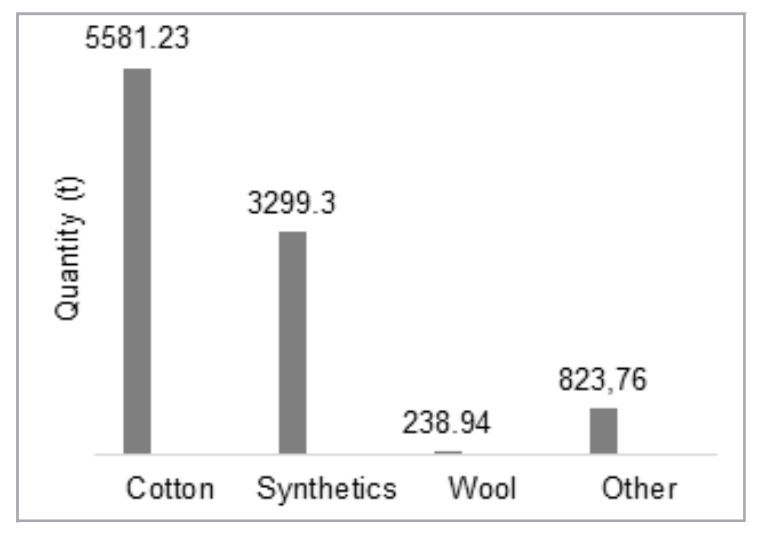

Figure 3. Average quantity of apparel cutting waste by raw material composition (2012-2014)

The comparison of the quantity of textile waste for the period 2009-2011 with the period 2012-2014 shows a small difference in the average total quantity of waste, as well as a small difference in terms of the quantities of waste according to the raw material composition. The waste stream mainly consists of cotton and cotton blends -11057.81 tonnes, 7002.7 tonnes of synthetic or artificial fibres, 593.82 tonnes of wool or fine animal hair and 1606.4 tonnes of waste with other raw material content.

The data from the previous research by the authors on this topic [11, 12] annually show 3333 tonnes of apparel cutting waste (1.7 kg per capita), out of which 1607 tonnes of cotton waste, 1222 tonnes of synthetic and artificial fibres, 128 tonnes of waste of wool, silk and other animal hair and 375 tonnes of waste with other raw material content. In $94.2 \%$ of the apparel companies, the waste is being collected by the communal public enterprise and disposed at the local landfills where it is combusted. A much less used method is when the waste is collected by a licensed company $-3.49 \%$, an individual $-1.16 \%$ or a recycling company $-1.16 \%$.

This research shows that the amount of apparel cutting waste per year is a fairly constant value, in the range 3330-3340 tonnes. The variations are also small in terms of the quantities of waste according to the raw material composition. The same conclusion is reached with the comparison of the two three-year periods 2009-2011 and 2012-2014.

\section{Conclusion}

An average of 3377 tonnes of textile waste, more precisely the apparel cutting waste is annually generated in Macedonia. The comparison of the quantity of textile waste for the period 2009-2011 with the period 2012-2014 shows a small difference in the average total quantity of waste, as well as a small difference in terms of the quantities of waste according to the raw material composition. The amount of apparel cutting waste annually generated in Macedonia is a fairly constant value. A small increase in the amount of cotton waste was observed compared to the waste from synthetic and artificial fibres. One of the key challenges in recycling apparel cuttings is to provide the waste availability, consistency of the waste supply, so this research must be taken into consideration before any initiative regarding its recycling.

\section{References}

[1] K . Caulfield, Sources of textile waste in Australia, Disscusion paper, 2009.

[2] http://www.nacro.org.au/wp-composition/ uploads/2013/04/TEXTILE-WASTE-PAPER-March-2009final.pdf accsessed: 12.2.2017.

[3] H.L Chen, L.D. Burns, Environmental analysis of textile products, Clothing and Textiles Research Journal, 24(3) (2006) $248-260$.

[4] V. Srebrenkoska in:Sustainable Technologies and Chemical Industry, Treatment of textile wastes, Ed. M. Jašić, Tehnološki Fakultet, Tuzla 2013, p. 129-135.

[5] G. Kazakevičiūtè, et al. A Survey of textile waste generated in Lithuanian textil apparel and soft furniture industries, Environmental Research, Engineering and Management, 2(44) (2008), p. 41-48.

[6] M.Larney, A.M. Aardt, Case study: Apparel industry waste management: A focus on recycling in South Africa. Waste Management \& Research, 28(1) (2010) 36-43.

[7] Government of the Republic of Macedonia, Preliminary strategy for waste management in R. Macedonia 200082020

[8] www.twaste.com/recycling, accsessed: 12.2.2017.

[9] J. Brady, Enviromental Management in Organizations, Institute of Environmental Management and Assessment, The IEMA Handbook, 2010, p. 52-58. 
[10] S.Jordeva, D. Trajkovic, E.Tomovska, K. Zafirova, Tekstilna industrija i tekstilni otpad u R.Makedoniji, Tekstilna Industrija, 61(4) (2014) p. 29- 32.

[11] State Statistical Office of Macedonia: http://www.stat.gov. mk, accsessed: 21.3.2017.

[12] S. Jordeva, E.Tomovska, D.Trajkovic, K. Zafirova, Current state of pre-consumer apparel waste management in Macedonia, Fibres\&Textiles in Eastern Europe, 23 (1) 2015 p.13-16.
[13] E.Tomovska, S. Jordeva, D.Trajkovic, K. Zafirova, Preconsumer apparel waste management in Macedonia, Book of proceeding 6th International Conference of Textile, Tirana 2014, p. 247-253.

\section{Izvod}

\section{ODRŽIVOST TEKSTILNOG OTPADA U MAKEDONIJI}

Sonja Jordeva ${ }^{1}$, Elena Tomovska² ${ }^{2}$ Kiro Mojsov ${ }^{1}$, Saška Golomeova-Longurova ${ }^{1}$, Stefan Maksimov ${ }^{1}$

${ }^{1}$ Tehnološko-tehnički fakultet, Univerzitet “Goce Delčev", Štip, Makedonija

${ }^{2}$ Tehnološko-metalurški fakultet, Univerzitet "Ćirilo i Metodije", Skopje, Makedonija

U Makedoniji se, kao zemlji sa razvijenom odevnom industrijom, stvara znatna količina pre-potrošačkog tekstilnog otpada, tačnije krojnog otpada. Cilj ovog rada je da se napravi tačna procena njegove količine, као i kategorizacija na osnovu sirovinskog sastava kao uslov za dalje postupanje sa njim. Pre bilo kakve inicijative za reciklažu tekstilnog otpada, treba napraviti analizu I videti da li njegova količina i kvalitet mogu osigurati kontinuitet procesa reciklaže. Analiza pokazuje da je u periodu od 2009. do 2014. godišnji prosek generisanog krojnog otpada iznosio 3.377 tona. Otpad od pamuka i mešavine pamuka je najzastupljeniji. Uprkos konstantnoj količini otpada od krojenja na godišnjem nivou i brojnih razloga za njegovu reciklažu, skoro sva ova količina završava na deponijama.
(STRUČNI RAD)

UDK 677:628.4.042:502.174.1 (497.7)

otpad, reciklaža 